\title{
APLIKASI UJIAN ONLINE PADA SMK MA'ARIF BANDUNG BERBASIS WEB
}

\author{
Ade Mubarok ${ }^{1}$, Mochammad Chandra Kurniawan ${ }^{2}$ \\ ${ }^{1}$ Jurusan Sistem Informasi, Universitas BSI Bandung \\ Jalan Sekolah internasional No.1-6, Antapani, Kota Bandung 40282 \\ ade.amb@bsi.ac.id \\ ${ }^{2}$ Jurusan Sistem Informasi Akuntansi, AMIK Bina Sarana Informatika \\ Jalan Sekolah internasional No.1-6, Antapani, Kota Bandung 40282 \\ chandra@passionit.co.id
}

\begin{abstract}
System test conducted by SMK Ma'Arif Bandung, the implementation is still in the conventional manner in which any midterm or final exams spent five reams of paper and time correction test results require a minimum of 3 days. So SMK Maarif should use different test systems. System exam in question is an online exam system where paper used can be reduced $90 \%$ and a time correction of exam results of $100 \%$. The method used is a method WSDM( Web Site Design Method) that is user-centered approach to the development of the website with the application model based on the information needs of user groups. With the online test this system, vocational Ma'Arif could reduce the budget and the time it takes relatively little that is more effective and efficient
\end{abstract}

Keywords : Online Exams, WSDM, Application Model, Website.

Abstrak - Sistem ujian yang dilakukan oleh SMK Ma'arif Bandung, pada pelaksanaannya masih dengan cara konvensional dimana setiap ujian tengah semester ataupun ujian akhir semester menghabiskan 5 rim kertas dan waktu pengkoreksian hasil ujian memerlukan minimal 3 hari. Sehingga SMK Ma'arif harus menggunakan sistem ujian yang berbeda. System ujian yang dimaksud adalah system ujian online dimana kertas yang digunakan dapat dikurangi $90 \%$ dan waktu pengkoreksian hasil ujian sebesar 100\%. Metode yang digunakan adalah metode WSDM (Web Site Design Method) yaitu pendekatan terpusat pada pengguna untuk pengembangan situs web dengan model aplikasi yang berdasarkan pada kebutuhan informasi dari kelompok pengguna. Dengan adanya system ujian secara online ini, SMK Ma'arif bisa mengurangi anggaran dan waktu yang dibutuhkan relatif sedikit sehingga lebih efektif dan efisien.

Kata kunci : Ujian online, WSDM, Model aplikasi, Website.

\section{PENDAHULUAN}

Internet merupakan bentuk dunia lain alias maya yang kehadirannya telah membentuk sistem kehidupan yang baru pula. Kecanggihan teknologi ini telah mampu menjawab tantangan hambatan jarak, waktu dan kondisi. Website merupakan salah satu layanan yang ditawarkan oleh internet diantara layananlayanan lainya. Menurut Pohan (2007:1) mengemukakan bahwa "Web pada awalnya adalah ruang informasi dalam internet dengan menggunakan teknologi hypertext, 
pemakai dituntun untuk menemukan informasi dengan mengikuti link yang disediakan dalam dokumen web yang ditampilkan dalam browser web". Indonesia merupakan negara dengan jumlah pengguna internet terbanyak ketujuh didunia yaitu diangka 58 juta orang. Sehingga akan berimbas kepada dunia pendidikan yang mengarah pada konsep web-based application.

Sama halnya yang terjadi di SMK Ma'arif Bandung, pada pelaksanaan ujian tengah semester dan ujian akhir semester masih menggunakan ujiannya secara konvensional yang mengakibatkan anggaran yang butuhkan cukup besar dan waktu pengkoreksian hasil ujian juga membutuhkan waktu yang relative lama. Sehingga SMK Ma'rif membuat keputusan dengan mengganti system ujian yang konvensional dengan ujian online berbasis web, dimana soal-soal ujian sebelumnya dicetak dan kemudian diberikan ke siswa peserta ujian. Dengan system ujian online soal-soal ditanam disebuah aplikasi berbasis web, sehingga siswa peserta ujian tinggal mengaksesnya dengan mudah dan cepat.

\section{METODE PENELITIAN}

Ada beberapa tahapan atau prosedur yang penulisan lakukan dalam penelitian ini, yaitu :

1. Metode pengumpulan data

a. Observasi

Penulis langsung mengunjungi tempat dimana SMK Ma'rif Bandung dengan melihat dan menganalisa langsung proses ujian di sekolah tersebut sehingga didapatkan kelemahan dan kekurangan dari system yang berjalan.

b. Wawancara

Sebagai pendukung pengambilan keputusan, penulis juga melakukan wawancara dengan kepala sekolah SMK Ma'arif terkait ujian pelaksanaan ujian yang berjalan di sekolah tersebut.

c. Studi Pustaka

Supaya lebih jelas dalam penyusunan penelitian ini, penulis juga mengambil teori-teori dari berbagai sumber yang berasal dari buku, jurnal dan situs yang terkait dengan data dan informasi yang dibutuhkan.

2. Metode Pengembangan Sistem

Metode yang digunakan dalam penelitian ini dengan cara WSDM (Web Site Design Method) dengan tahapannya yaitu:

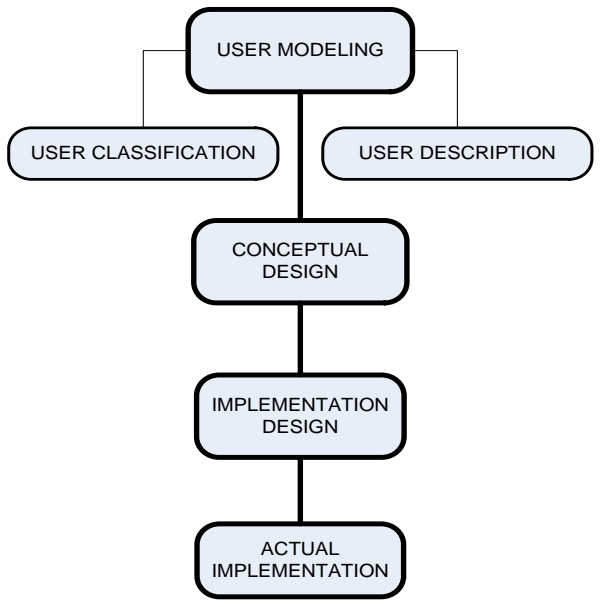

Gambar 1.

Langkah-langkah metode WSDM

a. Model Pengguna (User Modeling)

1) Klasifikasi Pengguna (User Classification)

Langkah pertama untuk menggunakan metode WSDM adalah mengidentifikasi dan mengklasifikasikan pengguna websites. Salah satu cara untuk melakukannya adalah dengan melihat organisasi atau proses ujian yang nantinya akan dibangun menggunakan aplikasi berbasis web. Setiap organisasi dapat dibagi menjadi beberapa kegiatan. Setiap kegiatan akan melibatkan orang orang dalam organisasi tersebut. Orang - orang ini adalah pengguna 
paling potensial menggunakan websites ujian nantinya.

2) Deskripsi Pengguna (User Description)

Untuk mendeskripsikan pengguna terdapat dua fokus analisis yang berbeda. Fokus pertama adalah pada kebutuhan informasi, semua pengguna berpotensi memiliki kebutuhan informasi yang sama. Namun, pengguna dalam kelas tertentu mungkin berbeda tentang bagaimana informasi harus disajikan tergantung pada hasil klasifikasi pengguna. Fokus kedua adalah karakteristik pengguna, karakteristik ini akan memberikan informasi tentang bagaimana informasi harus disajikan.

b. Desain Konseptual (Conceptual Design)

Desain konseptual ini terdiri dari beberapa tahap diantaranya pemodelan objek dan navigasi desain. Tujuan dari pemodelan objek adalah untuk memodelkan informasi yang telah didapatkan dalam pendeskripsian pengguna. Tujuan dari navigasi desain adalah untuk mendesain link-link yang akan ditampilkan pada web sites yang berdasarkan kebutuhan pengguna.

c. Desain Implementasi

(Implementation Design)

Dalam langkah ini pada dasarnya adalah untuk merancang sebuah tampilan websites. Tujuannya adalah untuk menciptakan sebuah tampilan yang konsisten, menyenangkan dan efisien dalam penyampaian informasi.

d. Penerapan / Implementasi (The Actual Implementation)

Tahap terakhir dalam metode WSDM adalah penerapan / implementasi. Dalam hal ini adalah untuk menerapkan dalam pembuatan web dari hasil memodelkan pengguna, desain konseptual dan desain implementasi.

\section{PEMBAHASAN}

Peta Navigasi

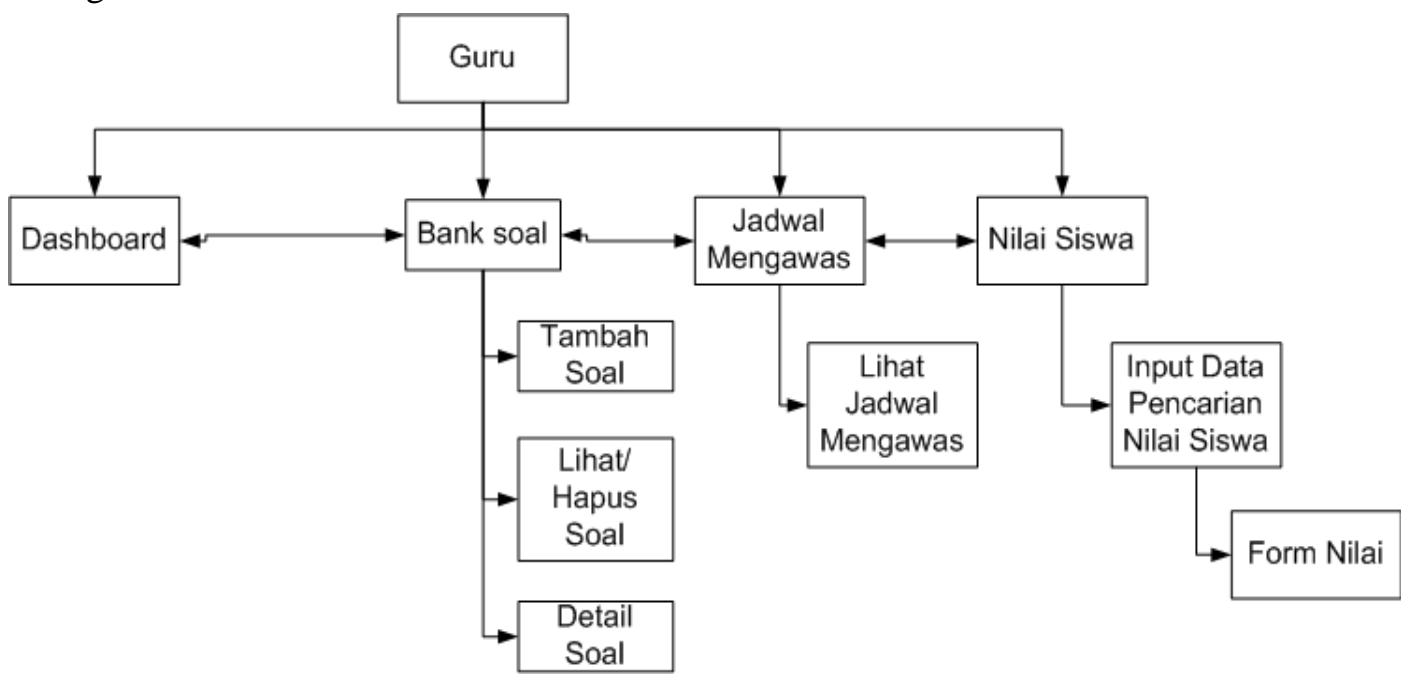

Gambar 2

Peta Navigasi Guru 
Penjelasan dari struktur navigasi adalah :

\section{Dashboard}

Dashboard adalah halaman utama untuk user, halaman ini menyambut user dengan menyuguhkan headline tentang ujian online seperti jadwal ujian online hari ini, ujian online yang sedang berlangsung, dan sebagainya.

2. Bank Soal

Halaman bank soal digunakan untuk melihat, membuat, mengubah, dan menghapus soal ujian yang dibuat oleh user yang nantinya soal tersebut akan ditampilkan kepada siswa peserta ujian online.

3. Jadwal Mengawas

Halaman ini digunakan untuk melihat jadwal mengawas user yang role-nya adalah guru secara keseluruhan.

4. Nilai Siswa

Halaman ini digunakan untuk melihat hasil ujian online siswa yang mengikuti ataupun tidak mengikuti ujian online.

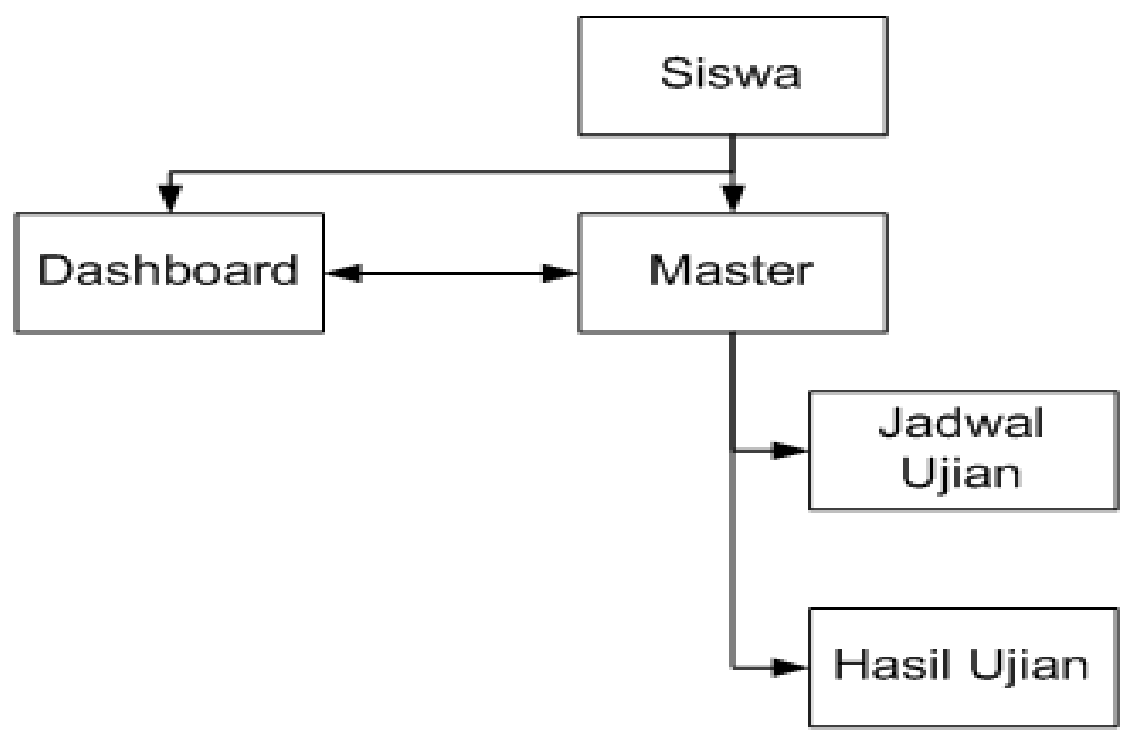

Gambar 3

Peta Navigasi Siswa

Penjelasan dari struktur navigasi siswa adalah :

a. Dashboard

Dashboard adalah halaman utama untuk user, halaman ini menyambut user dengan menyuguhkan headline tentang ujian online seperti jadwal ujian online hari ini, ujian online yang sedang berlangsung, dan sebagainya.

b. Master

Halaman ini digunakan untuk melihat jadwal ujian bagi siswa peserta ujian online dan untuk melihat hasil ujian online yang telah diikuti. 
1. Tampilan Web
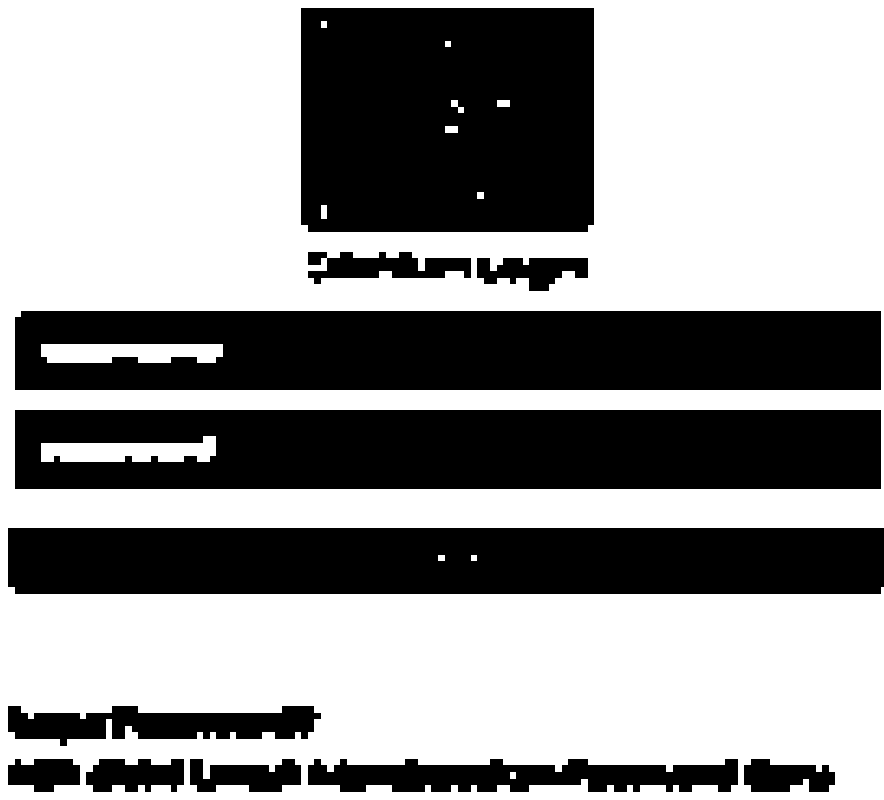

Gambar 4

Proses login

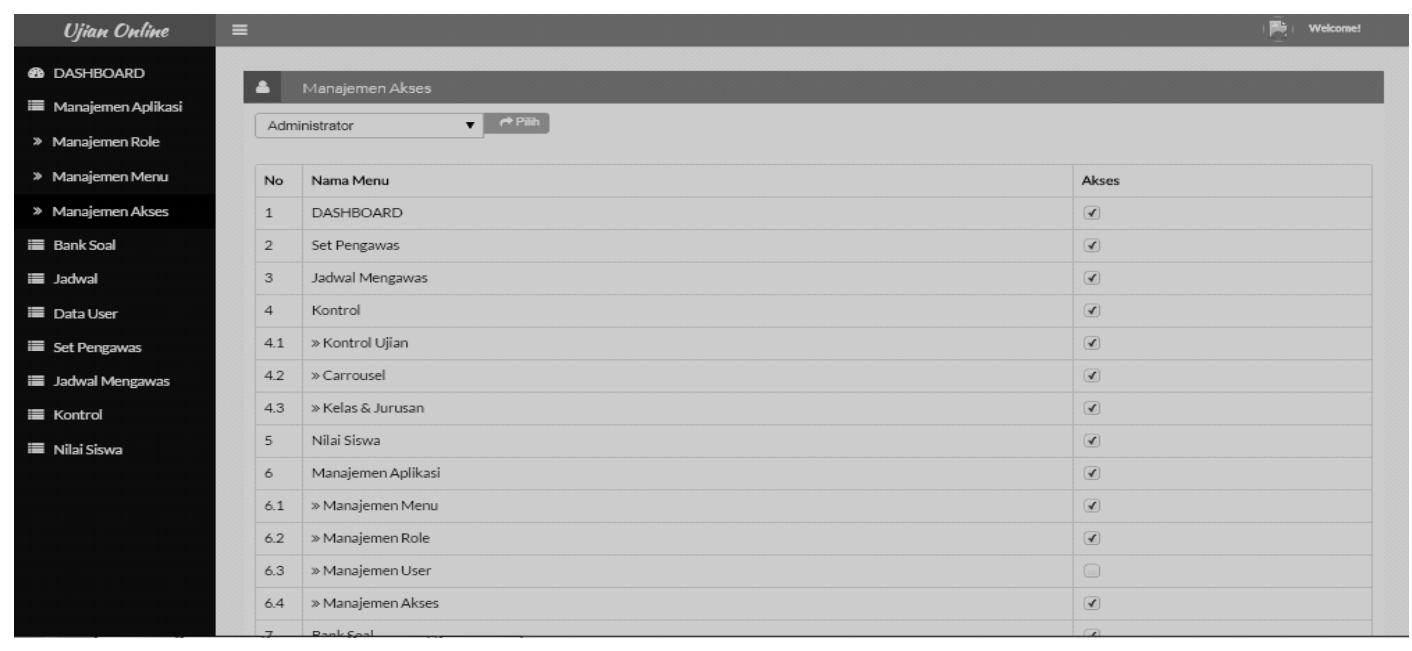

Gambar 5

Tampilan login berhasil 
2. View Bank Soal

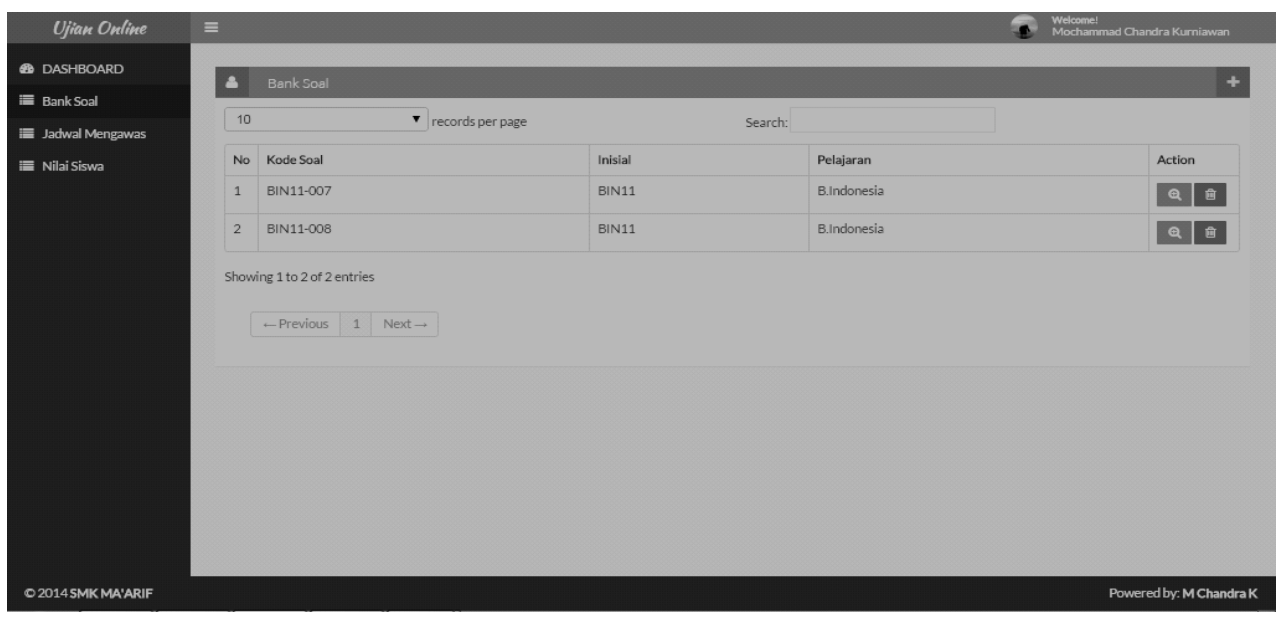

Gambar 6

Tampilan View Bank Soal
a. klik (icon plus) untuk menambah data bank soal.
b. klik al (icon loop) untuk melihat data soal yang sudah dibuat
c. klik $\quad$ (icon trash) untuk menghapus data bank soal

3. Tambah soal

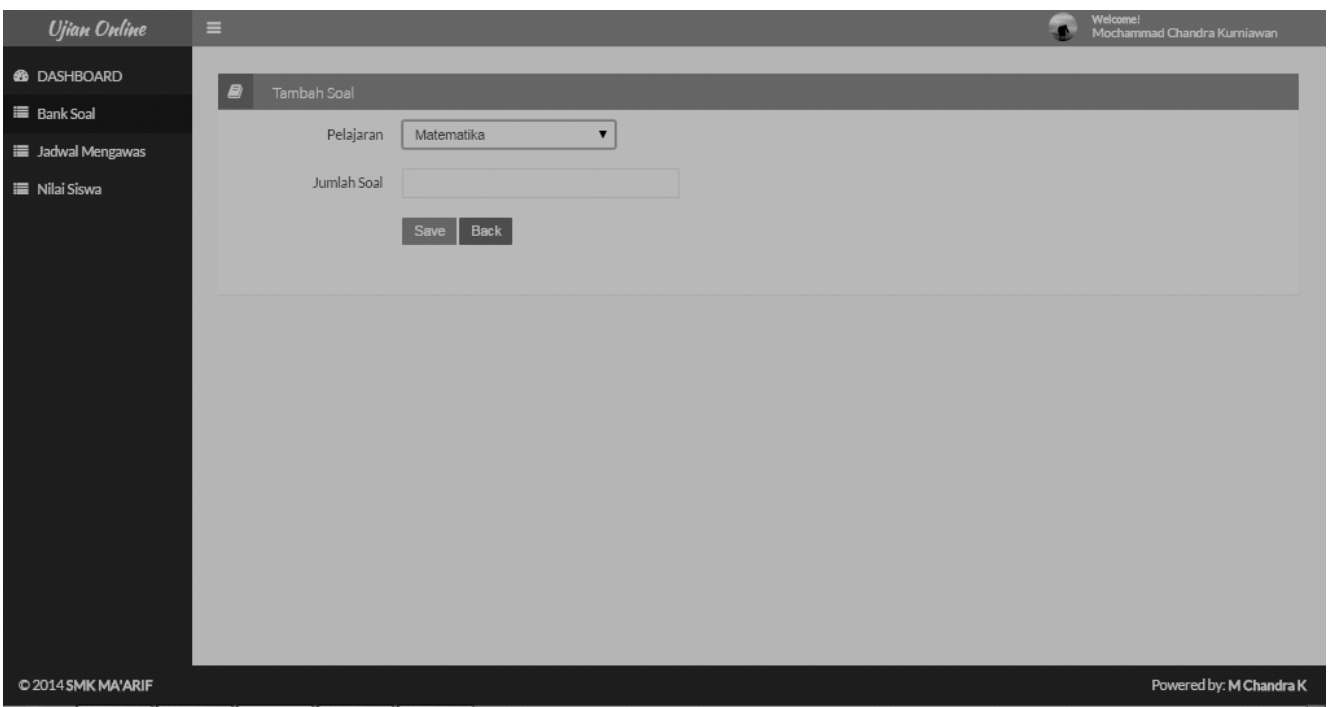

Gambar 7

Tambah Soal

a. klik untuk menyimpan data bank soal 


\section{b. klik untuk kembali ke view bank soal}

3. View pertanyaan yang dibuat pada bank soal

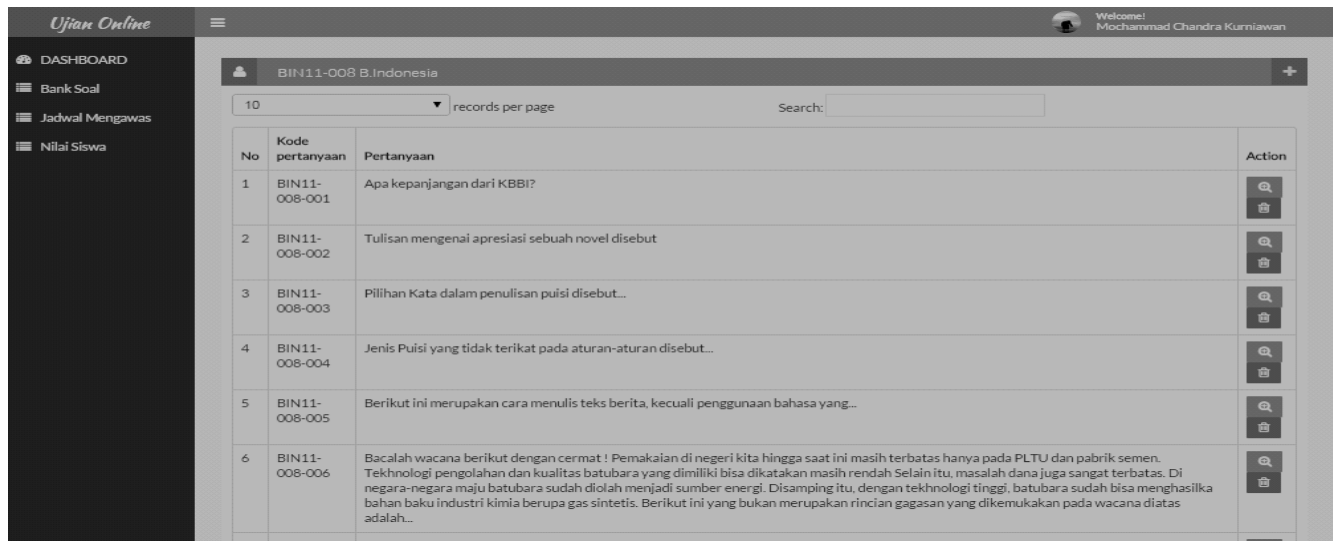

\section{Gambar 8}

View pertanyaan yang dibuat pada bank soal

a. klik $\quad$ (icon plus) untuk menambah pertanyaan.

b. klik al (icon loop) untuk melihat pilihan ganda pada pertanyaan yang dibuat c. klik $\quad$ (icon trash) untuk menghapus pertanyaan

4. Membuat pertanyaan pada bank soal

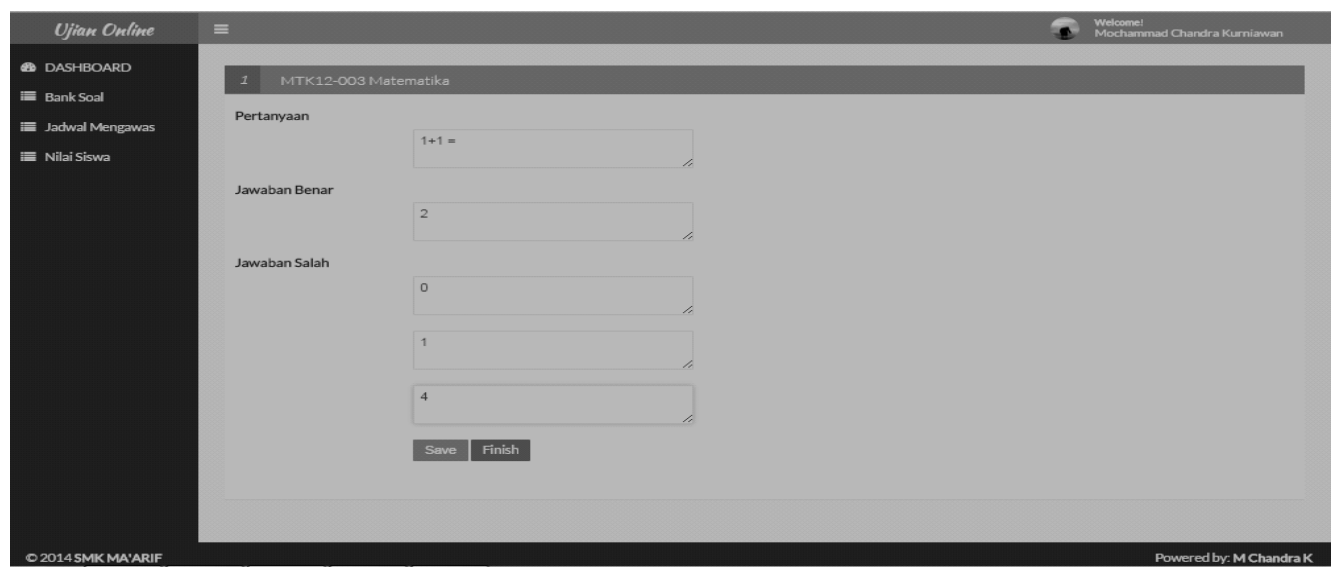

Gambar 9

Membuat pertanyaan pada bank soal
a. klik
untuk menyimpan pertanyaan yang dibuat
b. klik
untuk kembali ke view bank soal 


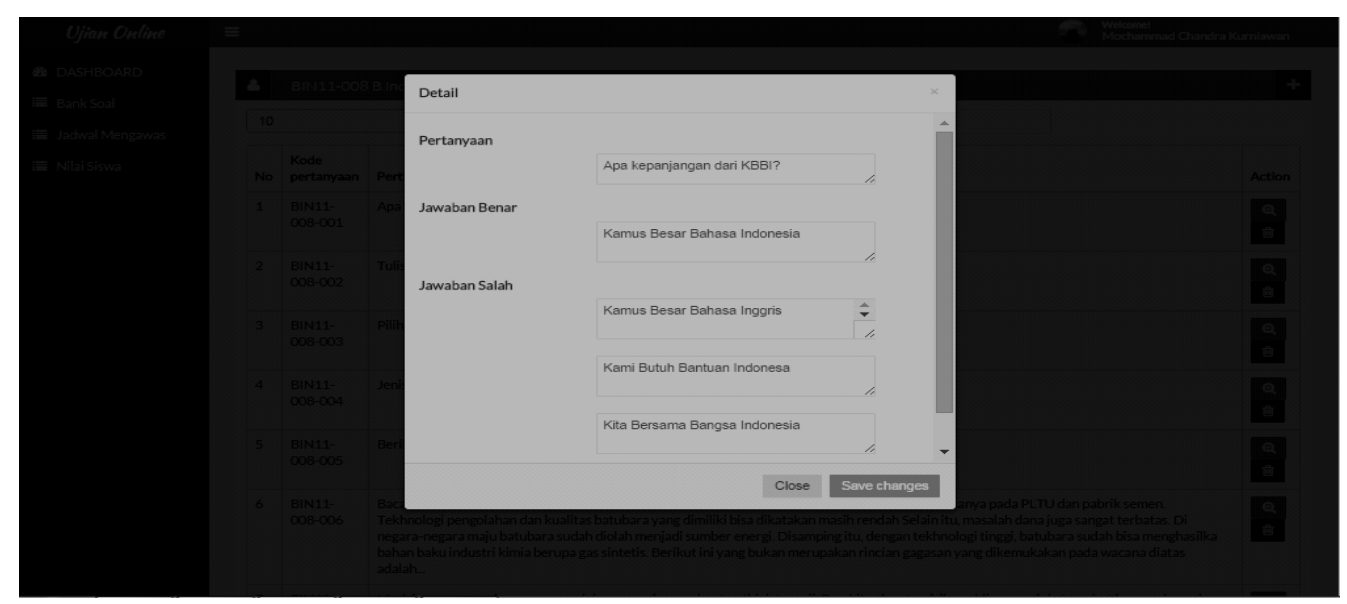

Gambar 10

Membuat pertanyaan pada bank soal

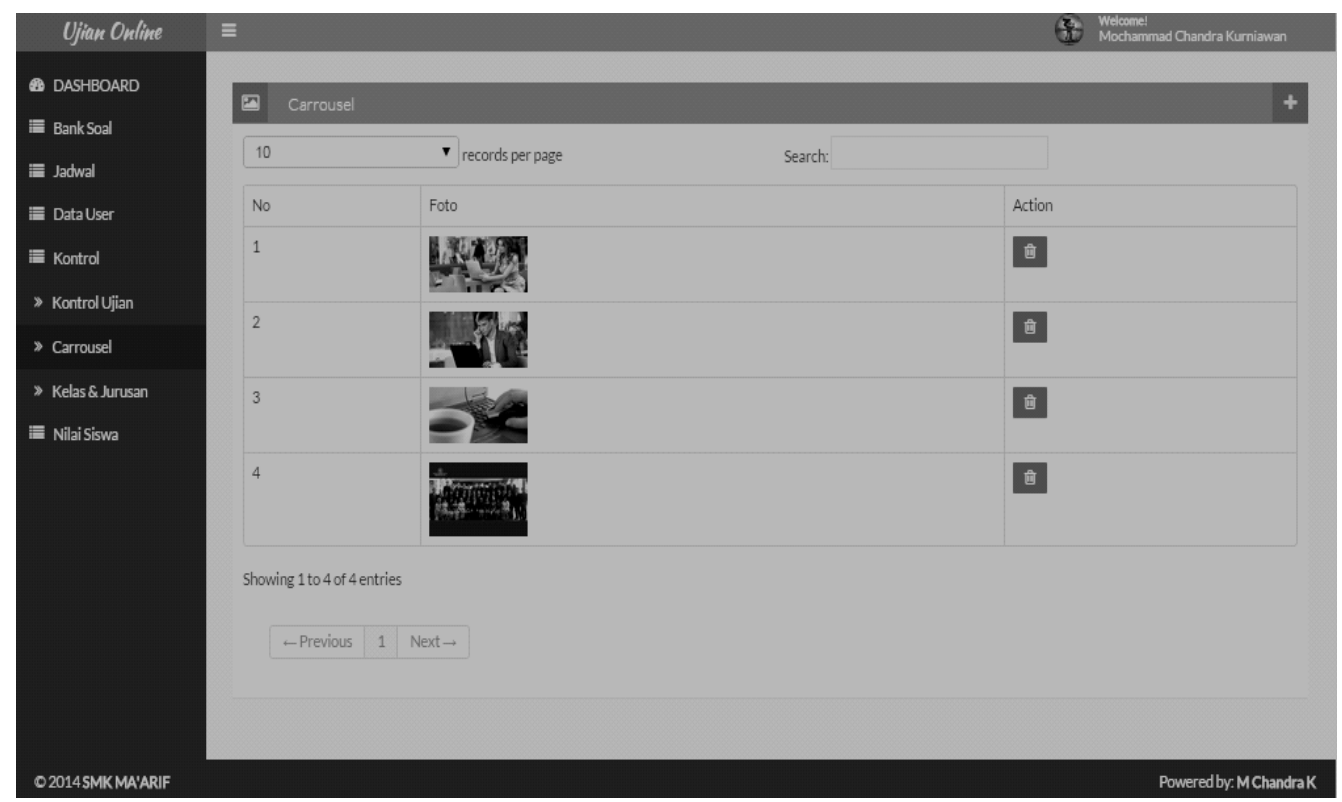

Gambar 11

Membuat pertanyaan pada bank soal dan Peserta 


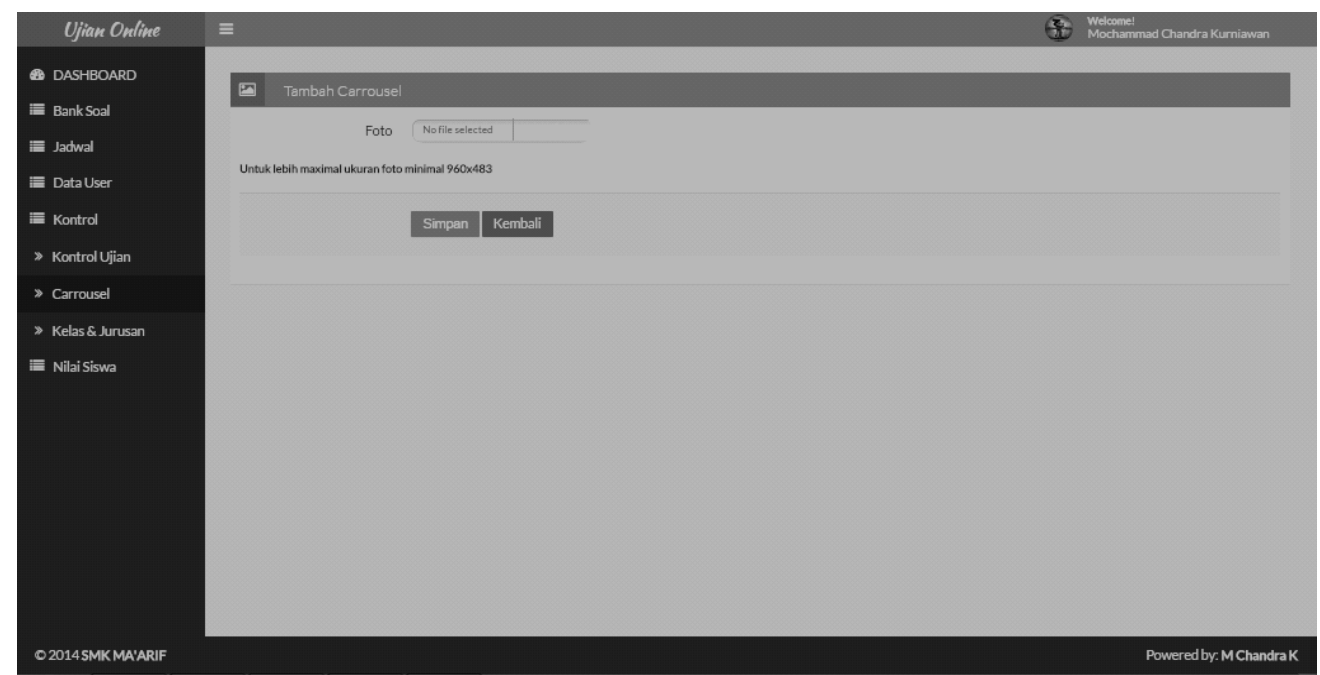

Gambar 12

Tampilan siswa memulai ujian

5. View melihat data jadwal ujian hari ini

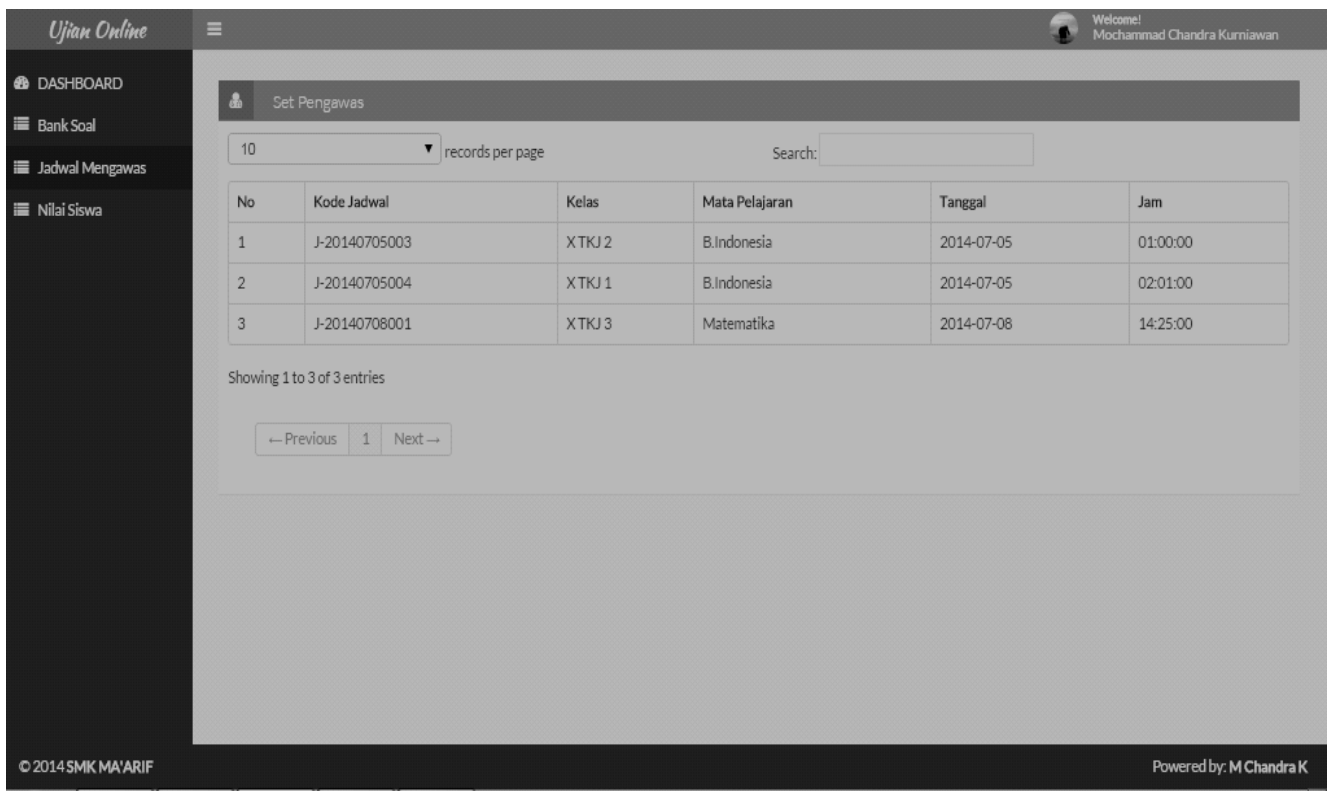

Gambar 13

View melihat data jadwal ujian hari ini 
6. Untuk memberi akses kepada siswa yang mengikuti ujian online

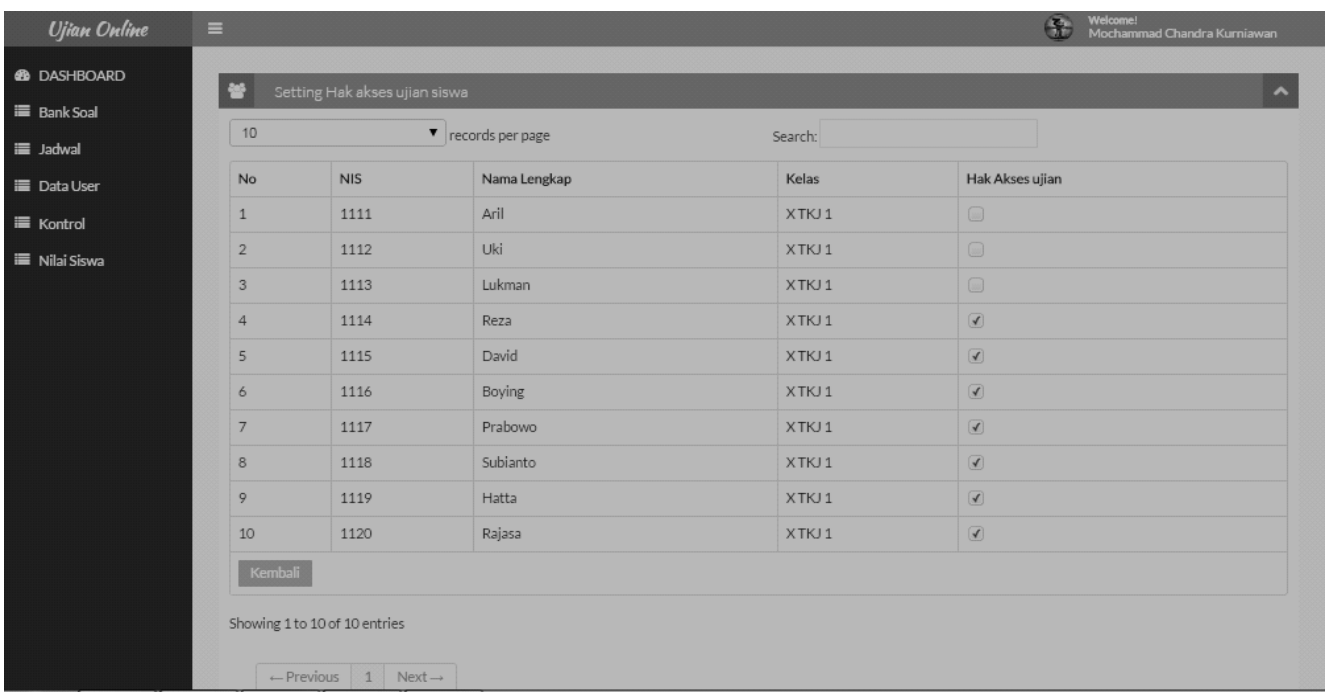

Gambar 14

Untuk memberi akses kepada siswa yang mengikuti ujian online

Pada fungsi ini siswa bisa diblok untuk tidak bisa mengikuti ujian dengan syarat tanda centang atau ceklis pada siswa dihilangkan.

8. View hasil ujian

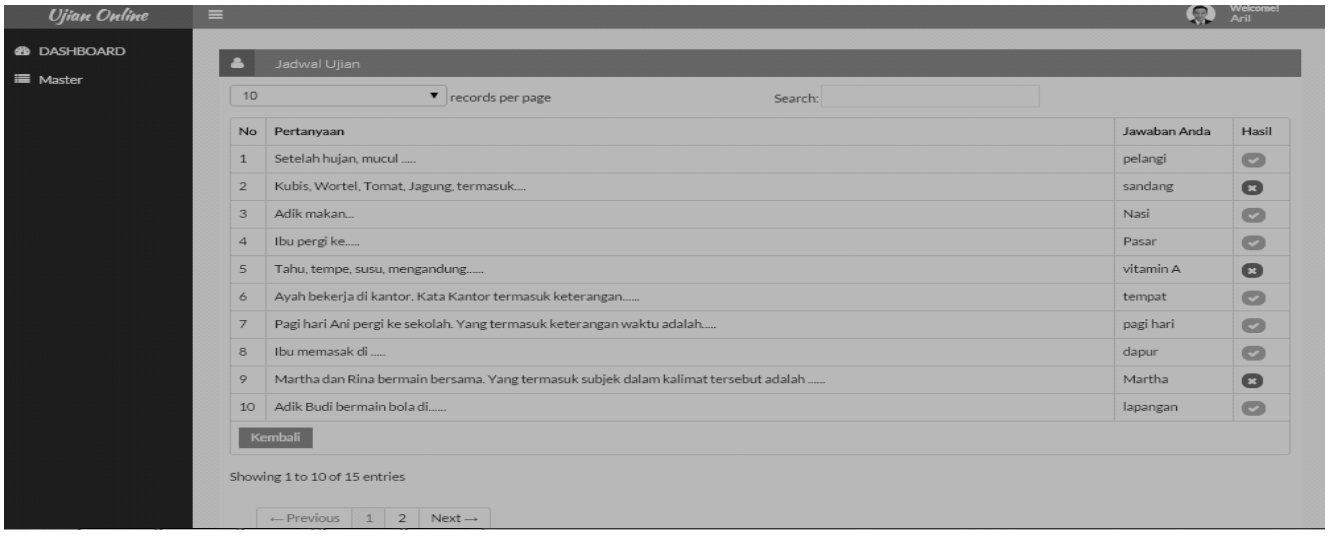

Gambar 14

view hasil ujian

a. Jika pada kolom hasil terdapat simbol $\stackrel{0}{-}$ berarti jawaban siswa benar

b. Jika pada kolom hasil terdapat simbol ${ }^{-}$berarti jawaban siswa salah ,untuk melihat jawaban yang benar siswa tinggal klik simbol ${ }^{-}$tersebut 
9. View untuk melihat jawaban yang benar

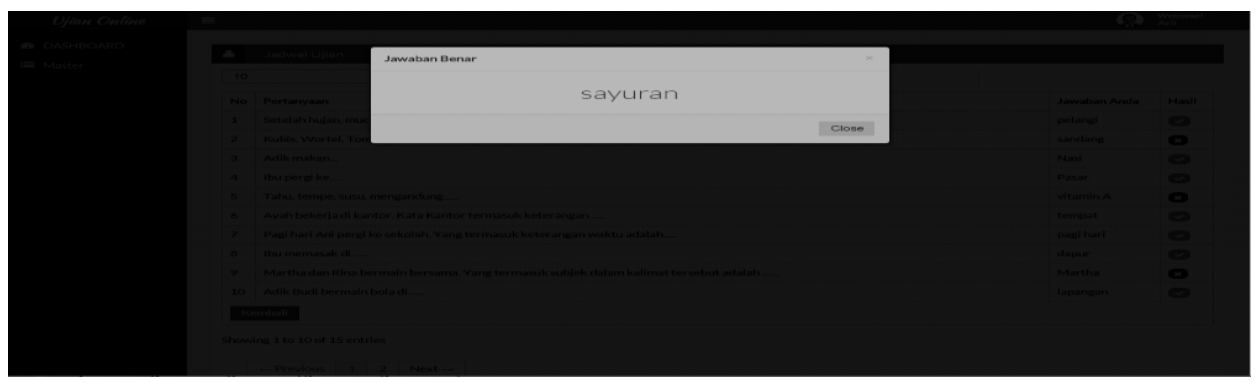

Gambar 15

View untuk melihat jawaban yang benar

10. Melihat hasil ujian yang telah diikuti

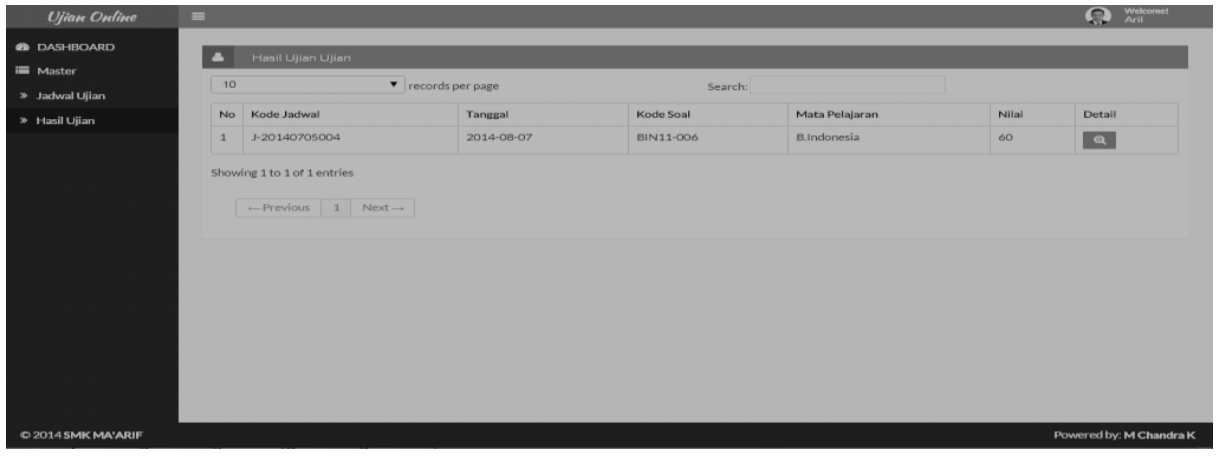

Gambar 16

Melihat hasil ujian yang telah diikuti

Klik a untuk melihat detail dari hasil ujian seperti ,melihat jawaban yang benar dan yg salah dari pertanyaan yang kita jawab.

11. View untuk membuat jawal ujian

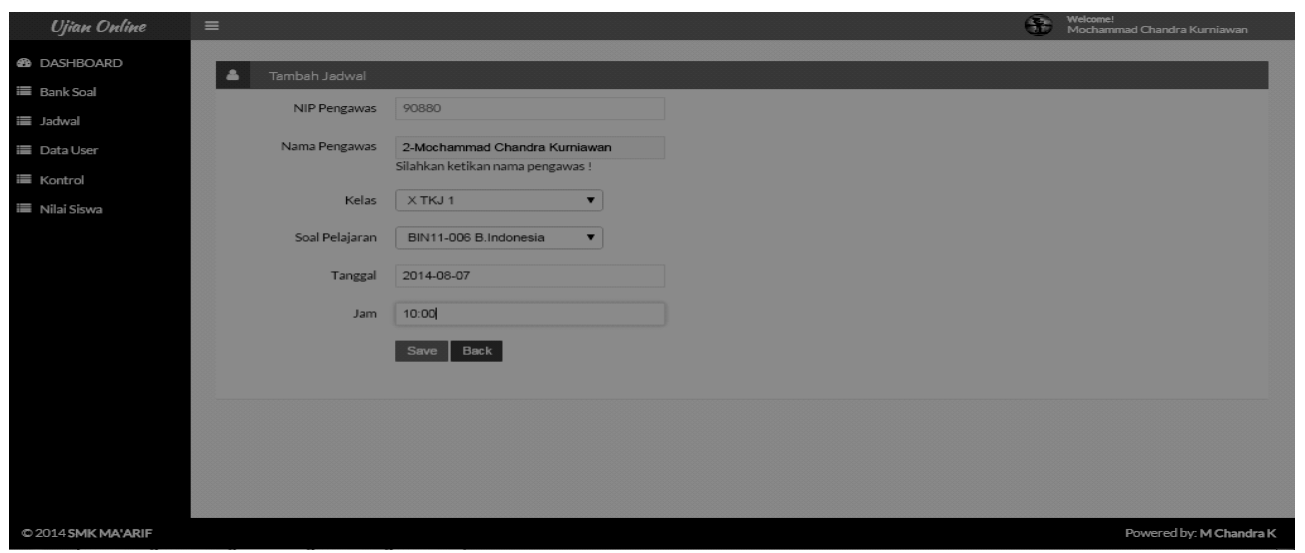

Gambar 17

Untuk membuat jawal ujian

12. View untuk melihat yang mengikuti ujian. 


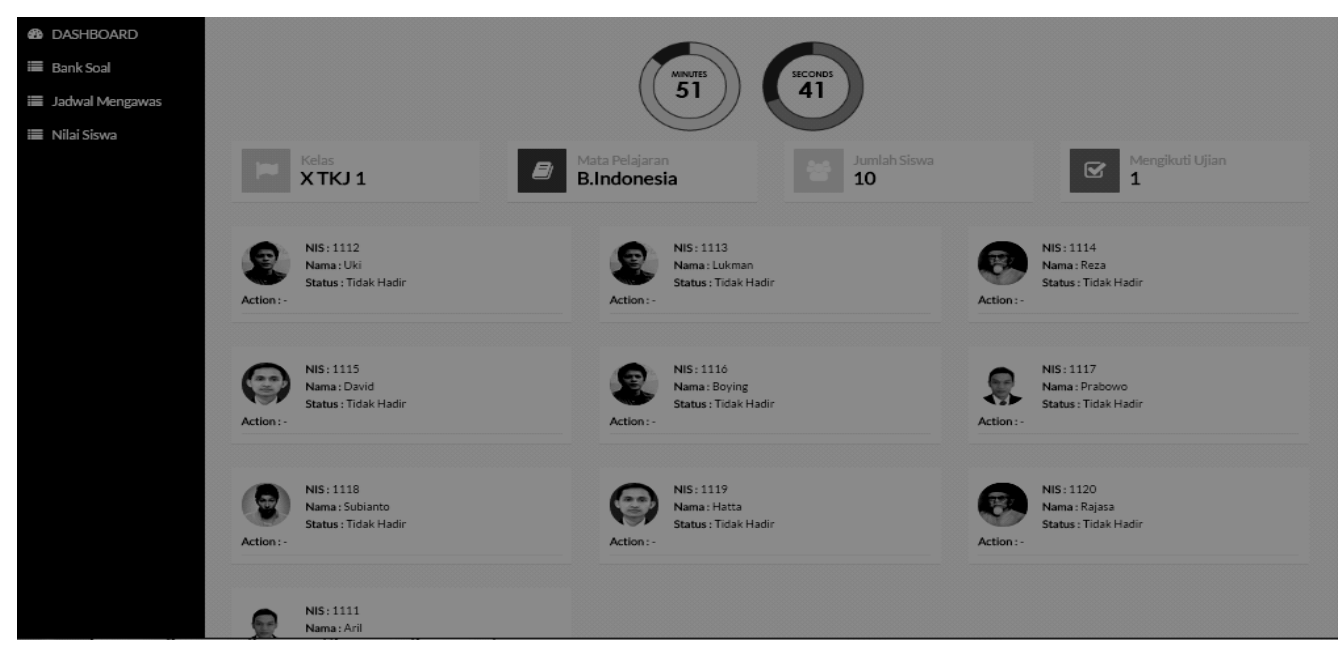

Gambar 18

View untuk melihat yang mengikuti ujian

Pada form ini pengawas bisa melihat siapa saja yang sedang mengikuti ujian dan siapa yang tidak mengikuti ujian,

13. View ujian untuk siswa

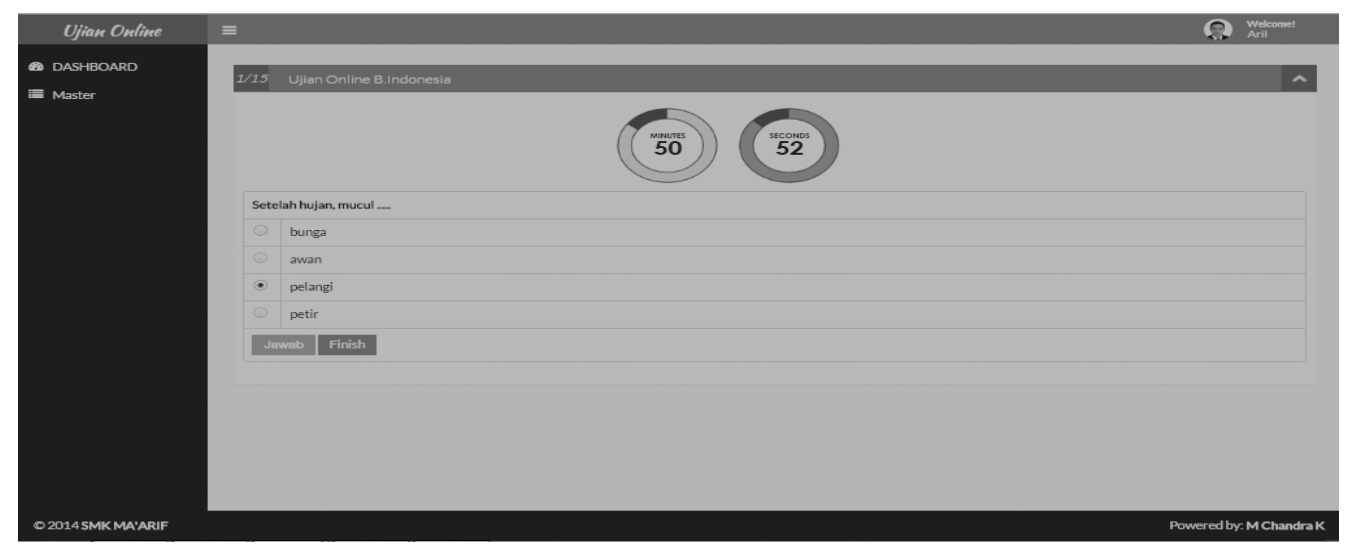

Gambar 19

View ujian untuk siswa

Pada form ini terdapat sisa waktu ujian ,pertanyaan dan pilihan ganda yang harus dipilih oleh siswa. 


\section{Kesimpulan}

Permasalahan pada proses ujian di SMK Ma'arif Bandung baik dari segi waktu dan finansial sudah berjalan lama, sehingga pengeluaran biaya dan waktu juga sudah terbuang banyak. Dengan adanya aplikasi ujian ini, proses ujian di SMK Ma'arif Bandung berjalan dengan lancar dan dari segi waktu juga finansial sangatlah murah. Sehingga proses ujian di SMK Ma'rif Bandung lebih efektif dan efisien.

\section{Saran}

Aplikasi ujian di SMK Ma'rif
Bandung yang dibuat masih banyak
kekurangannya, untuk itu penulis
menyarankan agar dari segi desain dan
kontennya harus lebih disempurnakan dan
untuk pengembangan selanjutnya dengan
berbasis android.

\section{REFERENSI}

Anneahira. 2008.Perkembangan Internet Masa Kini. Diambil dari :www.anneahira.com/perkembanganinternet-masa-kini.htm (21 April 2014).

Asmawati, Asri. 2013. Pengertian Ujian Online. Diambil dari : http://widuri.raharja.info/index.php?tit le=SI0813460668_Rancangan_Ujian_ Online_(IOU_:Integrated_Online_Uji an)_Pada_Konsentrasi_ILearning_Di_ Perguruan_Tinggi_Raharja (28 April 2014).

Asmawati, Asri. 2013. Pengertian XAMPP. Diambil dari

http://widuri.raharja.info/index.php?tit le=SI0813460668_Rancangan_Ujian_ Online_(IOU_:Integrated_Online_Uji an)_Pada_Konsentrasi_ILearning_Di_
Perguruan_Tinggi_Raharja (28 April 2014).

Ferdianto, Yosefa. 2013. Pengertian SQL. Diambil dari http://www.carawebs.info/2013/08/pe ngertian-sql.html (28 April 2014).

Mahendra, Alit. 2009. Macam-macam Struktur Navigasi. Diambil dari : http://www.oke.or.id/blog/2009/08/08/ macam-macam-stuktur-navigasi/ (28 April 2014).

Paragian, Yasser. 2014. Dalam 5 Tahun Terakhir, Jumlah Pengguna Internet Indonesia Naik $430 \%$. Diambil dari : http://id.techinasia.com/dalam-5tahun-terakhir-jumlah-penggunainternet-indonesia-naik-430-persengrafik/ (28 April 2014).

Pohan, I Husni. 2009. "Pemrograman Web Dengan HTML". Jakarta: Informatika.

Pratama, Widhi. 2012. "Codeigniter Cara Mudah Membangun Aplikasi PHP”. Jakarta: MediaKita.

Simarmata, Janner. 2010. "Rekayasa Web". Yogyakarta: Andi.

Syukur, Mark Ade. 2001. "Aplikasi Web Dengan Mysql dan PHP”. Yogyakarta: Andi.

Troyer, De O.M.F dan C.J Leune. 2009. Metode WSDM. Diambil dari : http://www7.scu.edu.au/1853/com185 3.htm (28 April 2014). 